New Challenges for UNICEF 
Also by Yves Beigbeder

INTERNATIONAL MONITORING OF PLEBISCITES, REFERENDA AND

NATIONAL ELECTIONS: Self-determination and Transition to Democracy

*JUDGING WAR CRIMINALS: The Politics of International Justice

LE HAUT COMMISSARIAT DES NATIONS UNIES POUR LES REFUGIES

*THE INTERNAL MANAGEMENT OF UNITED NATIONS ORGANIZATIONS: The Long Quest for Reform

THE ROLE AND STATUS OF INTERNATIONAL HUMANITARIAN VOLUNTEERS AND ORGANIZATIONS: The Right and Duty to Humanitarian Assistance

THE WORLD HEALTH ORGANIZATION (with the collaboration of Mahyar Nashat, Marie-Antoinette Orsini and Jean-François Tiercy)

*also from the same publishers 


\section{New Challenges for UNICEF}

Children, Women and Human Rights

Yves Beigbeder 


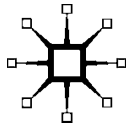

(C) Yves Beigbeder 2001

Softcover reprint of the hardcover 1st edition 2001 978-0-333-80047-8 All rights reserved. No reproduction, copy or transmission of this publication may be made without written permission.

No paragraph of this publication may be reproduced, copied or transmitted save with written permission or in accordance with the provisions of the Copyright, Designs and Patents Act 1988, or under the terms of any licence permitting limited copying issued by the Copyright Licensing Agency, 90 Tottenham Court Road, London W1T 4LP.

Any person who does any unauthorised act in relation to this publication may be liable to criminal prosecution and civil claims for damages.

The author has asserted his right to be identified as the author of this work in accordance with the Copyright, Designs and Patents Act 1988.

First published 2001 by

PALGRAVE

Houndmills, Basingstoke, Hampshire RG21 6XS and 175 Fifth Avenue, New York, N. Y. 10010

Companies and representatives throughout the world

PALGRAVE is the new global academic imprint of St. Martin's Press LLC Scholarly and Reference Division and Palgrave Publishers Ltd (formerly Macmillan Press Ltd).

ISBN 978-1-349-42055-1 ISBN 978-0-230-59557-6 (eBook)
DOI 10.1057/9780230595576

This book is printed on paper suitable for recycling and made from fully managed and sustained forest sources.

A catalogue record for this book is available from the British Library.

Library of Congress Cataloging-in-Publication Data

Beigbeder, Yves.

New challenges for UNICEF : children, women, and human rights / Yves Beigbeder

p. $\mathrm{cm}$.

Includes bibliographical references and index.

ISBN 0-333-80047-8 (cloth)

1. UNICEF. 2. Children-Legal status, laws, etc. 3. Children's rights. 4. Child welfare. I. Title.

K639.B45 2001

$362.7-d c 21$

2001035792

$\begin{array}{llllllllll}10 & 9 & 8 & 7 & 6 & 5 & 4 & 3 & 2 & 1\end{array}$

$\begin{array}{llllllllll}10 & 09 & 08 & 07 & 06 & 05 & 04 & 03 & 02 & 01\end{array}$ 


\section{Contents}

List of Figures and Tables vii

Foreword ix

Preface and Acknowledgements $\quad$ xi

List of Abbreviations $\quad \mathrm{xv}$

1 The Creation of UNICEF 1

Organizations which preceded UNICEF 1

The creation and mandate of UNICEF 11

The disputed extension of the Fund 12

Conclusion 16

2 An Expanding Mandate 18

Maurice Pate - 1947-1965 20

Henry R. Labouisse - 1965-1979 24

James P. Grant - 1980-1995 29

Carol Bellamy - 1995-(2004) 37

Conclusion 41

3 Structure and Finances 43

Formal structure 44

The extended family 49

Funding the Fund $\quad 56$

Conclusion $\quad 59$

4 Children's Health: the Main Programme 61

Institutional cooperation between UNICEF and WHO 62

Comprehensive or selective primary health care? 65

$\begin{array}{ll}\text { The promotion of breastfeeding } & 69\end{array}$

The Safe Motherhood Initiative 73

The Bamako Initiative $\quad 76$

The immunization of all the world's children $\quad 79$

$\begin{array}{ll}\text { The eradication of poliomyelitis } & 81\end{array}$

The Children's Vaccine Initiative and its successor 83

Fighting the AIDS epidemic $\quad 86$

A renewed WHO/UNICEF partnership $\quad 89$

$\begin{array}{ll}\text { Conclusion } & 90\end{array}$ 
5 Nutrition, Education, Sanitation 93

Food aid and nutrition $\quad 93$

Education $\quad 100$

Water supply and environmental sanitation $\quad 107$

Conclusion 113

6 Natural and Man-Made Emergencies 116

The humanitarian role of UNICEF 117

UNICEF's current mandate 118

Humanitarian dilemmas 121

$\begin{array}{ll}\text { Recent humanitarian operations } & 122\end{array}$

Child soldiers 130

Landmines - 'toxic pollution' 138

Conclusion 140

7 Advocating Children's Rights 145

The Convention on the Rights of the Child 146

Gender issues $\quad 155$

Child labour $\quad 163$

Purchasing slaves in Sudan $\quad 168$

Advocating debt relief 169

Indiscriminate economic sanctions $\quad 171$

$\begin{array}{ll}\text { Conclusion } & 172\end{array}$

8 Internal Management Issues 177

Assessments, criticisms and recommendations $\quad 178$

The 1994 management study $\quad 180$

Fraud and losses in Kenya 181

Other audit reports $\quad 182$

The Management Excellence Programme (MEP) 184

Staff cuts and the morale issue 186

Conclusion 189

9 UNICEF's Challenges 191

The target group 192

Intervention strategies 193

Future focus of UNICEF's work 198

Conclusion 198

Notes 201

$\begin{array}{ll}\text { Select Bibliography } & 217\end{array}$

$\begin{array}{ll}\text { Index } & 219\end{array}$ 


\section{List of Figures and Tables}

\section{Figures}

1.1 The Declaration of Geneva 5

2.1 The mission of UNICEF 39

3.1 The role of the Executive Board of UNICEF 46

3.2 Mission and terms of reference of the NGO Committee on UNICEF 55

4.1 WHO/UNICEF/UNFPA Coordinating Committee on Health Terms of Reference (excerpts) 66

4.2 Selective Primary Health Care 67

5.1 How UNIMIX was created 99

8.1 UNICEF Guiding Principles for staff commitment and conduct

\section{Tables}

3.1 UNICEF total income 1991-98 57

3.2 Percentage of programme expenditures by sector 59 
This page intentionally left blank 


\section{Foreword}

The United Nations system had been on a roller-coaster ride in the postCold War era. Initial euphoria about the construction of a 'new world order' went up in smoke, literally, with the downing of Black Hawk helicopters and the unseemly display of dead American marines in Mogadishu. The ill-informed, yet understandable, giddiness about the expansive possibilities for international cooperation turned quickly into a day-after hangover that was still in effect as we blithely watched the Rwandan genocide. The 'end of history' debate ended as quickly as it had begun. And yet, 1999 was the annus mirabilis, or horribilis depending on your point of view, with vigorous international responses in Kosovo and East Timor.

The point here is not to discuss the relative successes or failures of these high-profile efforts, but rather to suggest the requirement to move beyond the ups and downs of today's headlines, to grapple seriously with the lowprofile details of multilateral cooperation in every arena. Well publicized efforts to foster peace and security are essential but so too are the day-today and often invisible struggles to improve lives and to enforce international norms. Eradicating poverty and disease, improving education, and providing succor to children and women around the world are as much the 'stuff' of multilateral cooperation as blue-helmeted soldiers.

In this respect, I commend Yves Beigbeder for analysing the 'New Challenges for UNICEF'. The organization is unusual among UN agencies in that it is well-known among the public in both rich and poor countries. Not only was UNICEF awarded the Nobel Peace Prize in 1965, its goodwill ambassadors and other celebrity supporters help burnish its reputation for seriousness and cost-effectiveness. Its $\$ 1$ billion annual budget comes from voluntary contributions - from governments, charities, businesses and the sale of popular greeting cards.

This volume is not, however, a puff piece or an official story. It fills an important void in the literature, not only about the study of the institution charged with the promotion of children's and women's rights and welfare but about international organization more generally. To put it simply, we know precious little about the functioning of intergovernmental secretariats in contemporary world affairs. How does a body like UNICEF operate among a myriad of state and non-state actors, aiming to fulfil its mandate by working in collaboration with governments, 
corporations, grass-roots groups, the military and non-governmental organizations? Does leadership matter, and if so how? Is the Convention on the Rights of the Child another piece of paper or a wedge for change and a meaningful tool for new projects?

The honest student or practitioner of international relations should be willing to admit that everyone is groping and coping to understand the contemporary world in which international organizations and we ourselves operate. Yet, there are mainly grand theories and how-to manuals, but little between the abstract analyses emanating from scholars and the mundane matters of bureaucrats. The common ground between them is too rarely ploughed.

One of the reasons is that too few observers understand academic and practitioner preoccupations. A trained lawyer who began his career at Nuremburg and spent almost 35 years in UN service before returning to teaching and writing, Yves Beigbeder is able, however, to speak to both officials and scholars. Both will find satisfying interpretations of over half a century of UNICEF's efforts. He paints convincing portraits of strong leaders (Henry Labouisse and Jim Grant), of an international agency whose field efforts in development and humanitarian relief have been complemented by normative efforts to protect and enhance children's and women's rights. At the same time, one of the few institutions within the UN system that has an almost universal reputation for effectiveness and rectitude has its shortcomings. And the author does not shy away from criticisms. One that I would have emphasized is the tensions and competition with other international agencies, the turf-consciousness that plagues the UN system generally.

For all of the goodwill and public recognition surrounding UNICEF, few objective studies of the organization have been undertaken. This is why the present volume is essential reading for students and practitioners of international organization.

Thomas G. Weiss, November 2000

Presidential Professor, Co-Director, UN Intellectual History Project The Graduate Center, The City University of New York

New York, NY, USA 


\section{Preface and Acknowledgements}

Most organizations in the United Nations system have been subjected since the 1980s to recurrent attacks. Industrialized countries want them to be more efficient, less costly, better coordinated among themselves and with other bodies working in the same field. The US lead in these criticisms and the US refusal to pay their dues to the UN proper and other UN bodies has proved a counterproductive blackmail which has paradoxically hampered the organizations' efforts to reform and has reduced their programmes. Developing countries want the organizations to spend more on development and less on peacekeeping, while they reject any attempt to erode their national sovereignty through humanitarian interventions.

UNICEF is one of the few privileged UN agencies which is well-known among the general public in both rich and poor countries and enjoys a reputation for efficiency as the only global institution providing humanitarian, emergency and development assistance to children. Its name is often cited favourably in press and radio reports and its 'good works' are visible on TV screens.

The agency was awarded the Nobel prize for peace in 1965. Its financing through voluntary contributions by governments, other organizations and foundations, and by individuals, its sales of greeting cards and the well-publicized presence on war or poverty scenes of goodwill ambassadors and other celebrity supporters also contribute to its popularity.

While UNICEF has generally escaped most of the criticisms addressed to the 'political' UN and to some specialized agencies or bodies such as UNESCO, UNIDO or UNCTAD, one of its challenges is to maintain its identity and its activities as a UN children's agency among other UN organizations having a broader mandate, which includes children, in their own field: can UNICEF have its own separate programmes in public health, WHO's domain; in food and nutrition, part of the FAO's concerns; in education, a substantial part of UNESCO's programmes; in child labour, one of the ILO's activities? Or, more generally, are UNICEF programmes too extended and diffuse, is UNICEF trying to embrace too much at the risk of being ineffective?

The problem of rivalry with the specialized agencies is not new: they tried unsuccessfully to 'abort' the birth of UNICEF in 1946, and some tensions have occurred between them and the agency from time to time. 
Is UNICEF apolitical? Like the specialized agencies, UNICEF has been created as a specialized body in principle separate from the 'political' UN. However, UNICEF is an intergovernmental body subject to the pressures or instructions given by members of its governing board, representatives of their own governments. The position of these governments is naturally influenced by national and international politics. UNICEF works in a number of countries in consultation with or with the consent of the governments concerned: the agency's work in those countries cannot but be also subject to internal national politics and international politics. Finally, UNICEF has at times taken position publicly to deplore or blame international or national decisions which affected the welfare of children in specific countries or areas. Hence the difficulty for UNICEF, shared with many other intergovernmental and non-governmental organizations (IGOs and NGOs) working in relief and development assistance, to be or to appear to be above politics.

Another challenge to UNICEF is fighting donor fatigue, in so far as its resources come exclusively from voluntary contributions by governments, governmental agencies, IGOs and NGOs, foundations, business firms and individuals. This is linked to the visible cost-effectiveness of UNICEF, to the constant demonstration that it has comparative advantages over other IGOs and NGOs, or that it necessarily and usefully complements or supplements their activities.

This raises the issue, applicable to UNICEF and to many other IGOs and NGOs, of the difficult (or impossible) assessment of the impact of the agency's work on the real world: have UNICEF's programmes exerted an effective influence on countries' leaders, government, administrations to the benefit of children's health, nutrition and education in their countries? Have they played a role other than rhetoric in this or that country's development? Can UNICEF really fight poverty in developing countries, without direct and effective role in the economy of these countries?

Finally, the success or failure of UNICEF's programmes is dependent not only on their applicability to regional, national and local conditions, on the availability of financial and other resources and on the energy, enthusiasm and integrity of the agency's staff, but on broader political, military, economic, social and cultural factors. The best soil would ideally be good governance, a healthy economy, civil peace and peace with neighbouring states: there would then be no need for international assistance. In the real world, help is needed in countries where more money goes to arms than to health, where ethnic and other strife oppose citizens, where civil or external war exhausts resources, where AIDS and 
malaria weaken or kill part of the population. Can UNICEF help in such circumstances?

Early in August 1999, two teenage Africans from Guinea died in flight in the open landing gear of an airliner between Conakry and Brussels. A letter was found in their clothes addressed to 'the excellencies and officials of Europe':

We suffer enormously in Africa. Help us. We have problems in Africa. We lack rights as children. We have war and illness, we lack food ... We have schools, but we lack education ... If you see that we have sacrificed our lives it is because we need your help to fight against poverty and to end wars. ${ }^{1}$

This tragic appeal may be the best justification for UNICEF's efforts. Even if the agency's effective assistance is limited by its limited resources, it does provide useful advice and material assistance to governments and people in need, and, importantly, it gives hope to many. What cause is more valuable and attractive than that of helping babies and children to survive, grow and develop into useful citizens through support in health, nutrition and education?

This book tries to keep a balance between praise where it is due, i.e. in most areas, and a few criticisms which have been expressed of some of its operations and management. The latter should not be hidden, any more than some of the conflicts or tensions with other UN agencies or NGOs: no organization is perfect and transparency is required by donors and supporters. Problems should be exposed and their causes explained, so that prevention and correction may be timely applied. These few 'shadows' should not detract from the many 'lights', UNICEF's useful contribution, at the global level, to the protection and welfare of children of all countries, and particularly in developing countries.

The book recalls UNICEF's predecessors, its creation in 1946, its original mandate and the evolution of its programmes, its structure, management and funding. It describes the agency's work in public health, food aid and nutrition, education and sanitation, and its role in natural and man-made emergencies. Its advocacy for the adoption of the Convention on the Rights of the Child and its assistance to governments in the implementation of the Convention is also reviewed. Internal management issues are also discussed while the final chapter summarizes current UNICEF challenges.

The book is based on UNICEF reports and internal documents, press releases as well as periodical publications for the general public, relevant 
books and articles. It is also based on a number of interviews with UNICEF serving or retired staff and other colleagues of UN agencies. Reference is often made to Maggie Black's two extensive, well documented historical books on the agency's life and activities from its creation in 1946 to the mid-1990s - The Children and the Nations: The Story of Unicef (1986), and a sequel, Children First: The Story of UNICEF, Past and Present (1996), both sponsored by UNICEF. Clearly, the present essay does not attempt to compete with Black's detailed reviews of UNICEF's work which constitute a unique reference source for the period covered.

The essay is written as an individual, independent research work, not sponsored or guided by UNICEF. As such, the book does not claim to be a comprehensive review of all the agency's programmes and achievements. Its purpose is to present in a relatively brief form some of the important events in the agency's life, its main programmes, the challenges and problems faced and what solutions, if any, were found.

Thanks are addressed to staff in UNICEF in New York and in Geneva who helped me in obtaining relevant documentation and information, to retired colleagues for their useful advice, and to the helpful and patient staff in the UN and WHO Libraries in Geneva. Due credit is also given to UNICEF for giving permission to make references to and use a few excerpts from Maggie Black's book Children First: The Story of UNICEF, Past and Present (Oxford: Oxford University Press for UNICEF, 1996). The editing skills of Mandy Eggleston are gratefully acknowledged.

Finally, the author has written this book in a personal capacity: views and assessments are his own responsibility - they do not necessarily reflect the views of, nor commit in any way, UNICEF and the other organizations referred to in the following chapters.

\section{Notes:}

- The use of the word 'agency' in reference to UNICEF in the present book follows the same use in UNICEF publications. It does not affect the status of UNICEF as a Fund, a subsidiary body of the UN General Assembly: UNICEF is not a specialized agency of the UN.

- The sign $\$$ in the text refers to US\$. 


\section{List of Abbreviations}

$\begin{array}{ll}\text { ACABQ } & \text { Advisory Committee on Administrative and Budgetary } \\ & \text { Questions } \\ \text { ACC } & \text { Administrative Committee on Coordination } \\ \text { ARI } & \text { acute respiratory infections } \\ \text { CCH } & \text { WHO/UNICEF/UNFPA Coordinating Committee on } \\ & \text { Health } \\ \text { CDD } & \text { control of diarrhoeal diseases } \\ \text { cEDC } & \text { children in especially difficult circumstances } \\ \text { CERD } & \text { Convention on the Elimination of Racial Discrimination } \\ \text { CIDA } & \text { Canadian International Development Agency } \\ \text { CRB } & \text { Commission for Relief in Belgium } \\ \text { CSI } & \text { Christian Solidarity International } \\ \text { CVI } & \text { Children's Vaccine Initiative } \\ \text { ECHO } & \text { Humanitarian Office of the European Union } \\ \text { ECOSOC } & \text { Economic and Social Council } \\ \text { EPI } & \text { Expanded Programme on Immunization } \\ \text { FAO } & \text { Food and Agriculture Organization of the UN } \\ \text { FGM } & \text { Female genital mutilation } \\ \text { FLS } & \text { Financial and Logistic System } \\ \text { GAVI } & \text { Global Alliance for Vaccines and Immunization } \\ \text { GOBI/FF } & \text { Growth monitoring, Oral rehydration therapy, } \\ & \text { Breastfeeding, Immunization/ Food supplements, Family } \\ & \text { planning } \\ \text { GPA } & \text { Global Programme on AIDS } \\ \text { GPV } & \text { Global Programme for Vaccines and Immunization } \\ \text { IBFAN } & \text { International Baby Food Action Network } \\ \text { ICCB } & \text { International Catholic Child Bureau } \\ \text { ICESCR } & \text { International Covenant on Economic, Social and Cultural } \\ \text { ICPR } & \text { Rights } \\ \text { ICRC } & \text { International Covenant on Civil and Political Rights } \\ \text { IDD } & \text { International Committee of the Red Cross } \\ \text { IDEdine deficiency disorder } \\ \text { IFAD } & \text { Intensive District Approach to Education for All } \\ \text { IGO } & \text { International Fund for Agricultural Development } \\ \text { ILO } & \text { Inter-governmental organization } \\ & \text { International Labour Organization } \\ & \end{array}$




\begin{tabular}{ll} 
IMCI & Integrated Management of Childhood Illness \\
IMF & International Monetary Fund \\
IPEC & International Programme on the Elimination of Child \\
& Labour \\
IYC & International Year of the Child \\
JCGP & Joint Consultative Group on Policy \\
JCHP & Joint Committee on Health Policy \\
LRA & Lord's Resistance Army (Uganda) \\
MICS & Multiple Indicator Cluster Survey \\
MNT & maternal and neonatal tetanus \\
MSF & Médecins sans Frontières \\
Nats & Niños y Adolescentes Trabajores \\
NGO & non-governmental organization \\
NPO & National Professional Officers \\
OAS & Organization of American States \\
OAU & Organization of African Unity \\
ODA & Official development assistance \\
OECD & Organization for Economic Cooperation and Development \\
OIA & Office of Internal Audit \\
ORS & oral rehydration salts \\
ORT & oral rehydration therapy \\
PAHO & Pan American Health Organization \\
PHC & primary health care \\
PROMS & Programme Manager System \\
RRTs & Rapid Response Teams \\
RUF & Revolutionary United Front (Sierra Leone) \\
SCF & Save the Children Fund \\
SIAR & Scandinavian Institutes for Administrative Research \\
STD & sexually transmitted disease \\
UCI & Universal Children's Immunization \\
UK & United Kingdom \\
UN & United Nations \\
UNAIDS & Joint UN Programme on HIV/AIDS \\
UNAMET & UN Mission in East Timor \\
UNCTAD & UN Conference on Trade and Development \\
UNDP & UN Development Programme \\
UNESCO & UN Educational, Scientific and Cultural Organization \\
UNFPA & UN Fund for Population Activities \\
UNGA & UN General Assembly \\
UNHCR & UN High Commissioner for Refugees \\
UNICEF & UN Children's Fund \\
\hline
\end{tabular}




\begin{tabular}{|c|c|}
\hline UNIDO & UN Industrial Development Organization \\
\hline UNIFEM & UN Development Fund for Women \\
\hline UNIMIS-HR & $\begin{array}{l}\text { UN Integrated Management Information System - Human } \\
\text { Resources }\end{array}$ \\
\hline UNITA & National Union for the Liberation of Angola \\
\hline UNITAR & UN Institute for Training and Research \\
\hline UNRRA & UN Relief and Rehabilitation Administration \\
\hline UNRWA & $\begin{array}{l}\text { UN Relief and Works Agency for Palestine Refugees in the } \\
\text { Near East }\end{array}$ \\
\hline USA & United States of America \\
\hline USAID & US Agency for International Development \\
\hline VAD & vitamin A deficiency \\
\hline WFP & World Food Programme \\
\hline WHO & World Health Organization \\
\hline YWCA & Young Women Christians Association \\
\hline
\end{tabular}

